\title{
Proceedings of the International Conference of the WHO Collaborating Centre for Primary Oral Health Care and African and Middle-East Region of IADR, Faculty of Dentistry, Kuwait University, Kuwait, November 27-28, 2012
}

This conference was devoted to the inauguration of the Faculty of Dentistry as a WHO Collaborating Centre (WHOCC) for Primary Oral Health Care, which had been designated by the WHO Global Oral Health Programme in June, 2011, for a period of 5 years. This inaugural conference was part of the action plan of the WHOCC. The basic documents, the Terms of Reference and Action Plans 1-5 were prepared together with Prof. Poul Erik Petersen, Director of Global Oral Health Programme, WHO. The main keynote lecture 'Improving Global Oral Health through Primary Health Care - the Leadership Role of the World Health Organization' was delivered by Prof. Poul Erik Petersen. The WHOCC for Primary Oral Health Care and the Terms of Reference and Action Plan 1 were introduced by Dr. Jawad M. Behbehani, Director of the WHOCC and Dean of the Faculty of Dentistry, Kuwait University. Action Plans 2-5 were described by Prof. Eino Honkala and Dr. Sisko Honkala, who are coordinators of these. The WHOCC for Training and Research in Dental Public Health, Shahid Behesti University of Medical Sciences, Tehran, Iran, which is the other WHOCC for Oral Health in this region, was introduced by its director, Dr. Mohammad $\mathrm{H}$. Koshnevisan. Dr. Taleb Al-Sarraf described 'Government Oral Health Services in Kuwait' and Dr. J. Ariga intro- duced 'School Oral Health Programme in Kuwait' and 'Mobile Dental Care Services in Kuwait' with a video film.

In addition to the WHOCC for Primary Oral Health Care, there is another WHOCC for Acquired Immuno Deficiency Syndrome in Kuwait, which was introduced by Dr. Haya Altawalah. In this centre, research integral to the WHO's efforts to combat AIDS is conducted. In addition to annual workshops and symposia, the centre strives to keep abreast of the latest advances in virology. Another effort, the Kuwait National Programme for Healthy Living, an initiative to promote the health and well-being of individuals residing in the country, was described by Prof. Kazem Behbehani, Director of the Dasman Institute for Diabetes and Other Chronic Diseases. The plan has been created based on current data regarding the lifestyle choices of individuals residing in Kuwait and their impact on health in general and chronic diseases in particular.

The theme of the second day of this conference was devoted to the International Association for Dental Research (IADR). Prof. David Williams introduced a special IADR research agenda to reduce global oral health inequalities (GOHIRA). Prof. Sudesni Naidoo spoke on 'Ethics, Health and Human Rights in the Dental Curriculum in South Africa' and Dr. Elifuraha Mumghamba

\begin{tabular}{ll}
\hline KARGER & $\begin{array}{l}\text { ( ) 2014 S. Karger AG, Basel } \\
1011-7571 / 14 / 0237-0001 \$ 39.50 / 0 \quad \text { Karger } \\
\text { Open access }\end{array}$ \\
$\begin{array}{l}\text { E-Mail karger@karger.com } \\
\text { www.karger.com/mpp }\end{array}$ & $\begin{array}{l}\text { This is an Open Access article licensed under the terms of the } \\
\text { Creative Commons Attribution-NonCommercial 3.0 Un- } \\
\text { ported license (CC BY-NC) (www.karger.com/OA-license), } \\
\text { applicable to the online version of the article only. Distribu- } \\
\text { tion permitted for non-commercial purposes only. }\end{array}$
\end{tabular}


delivered remarks on the 'Primary Oral Health Care Approach in the Dental Curriculum'. Prof. Hien Ngo presented a lecture on 'Challenges in Implementing Preventive Programmes in the Developing Countries' and finally, Prof. Richard Simonsen described 'Challenges in Implementing Preventive Programmes in the Developed Countries'.

All presidents of IADR Divisions and Sections in the African and Middle East IADR region (AMER) were invited to this conference and to attend the AMER board meeting on the second day. All the invited keynote speakers were requested to write a manuscript for the proceedings of the conference, which has now been published as a supplement of Medical Principles and Practice, the international journal of Kuwait University's Health Sciences Centre. We are grateful to Prof. Azu Owunwanne, Ed-
itor-in-Chief, Prof. Ludmil Benov, Editor, the editorial office staff, and the reviewers of the manuscripts for their help with this supplement. We also acknowledge our appreciation and extend our thanks to Prof. Basil Nakib, Vice-President for Health Sciences Centre, for financing the publication of this supplement.

\section{Disclosure Statement}

The authors disclose no conflicts of interest.

Dr. Jawad M. Behbehani

Dean, Director of WHOCC, President, AMER

Prof. Eino Honkala

Vice-Dean for Research, Secretary, AMER 